$\begin{array}{ll}\text { Abstracta Iranica } & \begin{array}{l}\text { Abstracta Iranica } \\ \text { Revue bibliographique pour le domaine irano-aryen }\end{array} \\ & \text { Volume } \mathbf{3 4 - 3 5 - 3 6} \text { | } 2017 \\ \text { Comptes rendus des publications de 201 1-2013 }\end{array}$

\title{
Cecil John Edmonds. East and West of Zagros: Travel, War and Politics in Persia and Iraq,
} 1913-1921

\section{Oliver Bast}

\author{
(2) OpenEdition \\ Journals \\ Édition électronique \\ URL : http://journals.openedition.org/abstractairanica/48458 \\ DOI : 10.4000/abstractairanica.48458 \\ ISSN : 1961-960X \\ Éditeur : \\ CNRS (UMR 7528 Mondes iraniens et indiens), Éditions de l'IFRI
}

Référence électronique

Oliver Bast, «Cecil John Edmonds. East and West of Zagros: Travel, War and Politics in Persia and Iraq, 1913-1921 », Abstracta Iranica [En ligne], Volume 34-35-36 | 2017, document 1, mis en ligne le 15 juillet 2016, consulté le 03 octobre 2020. URL : http://journals.openedition.org/abstractairanica/48458 ; DOI : https://doi.org/10.4000/abstractairanica.48458

Ce document a été généré automatiquement le 3 octobre 2020.

Tous droits réservés 


\title{
Cecil John Edmonds. East and West of Zagros: Travel, War and Politics in Persia and Iraq, 1913-1921
}

\author{
Oliver Bast
}

\section{RÉFÉRENCE}

Cecil John Edmonds. East and West of Zagros: Travel, War and Politics in Persia and Iraq, 1913-1921. Edited and with an introduction by Yann Richard. Leiden - Boston: Brill, 2010, xxii + 377p., 37 illustrations n\&b, 5 cartes, appendices, index général. (Iran Studies, v. 4), ISBN 978-90-04-17344-6

1 East and West of Zagros are the memoirs of British officer, diplomat, and academic Cecil J. Edmonds (1889-1979) concerning his service between 1913 and 1921, first, as a junior diplomat and, later-during World War I and its immediate aftermath-as an (Assistant) Political Officer chiefly in Persia (including stints in Bushire, Shushtar, Dezful, Lorestan, Borujerd, Gilan, Qazvin, and Tabriz as well as occasional visits to Tehran) but also in Lower Mesopotamia and, for a very brief, but significant, interlude, in Transcaucasia. Yann Richard's meticulous edition of these - in the main - Iranrelated memoirs is timely because until now Edmonds has been far more well known, if not as a SOAS-based Kurdish studies academic during the 1950s, then for his inter-war period activities in Iraq, where he first, between 1919 and 1925, served as a Political Officer in the at that time highly turbulent Kurdish region, which led to the publication in 1957 of a personal account entitled Kurds, Turks and Arabs: Politics, Travel and Research in North-Eastern Iraq, 1919-1925 (London and New York: Oxford University Press), and later, from the mid-thirties through World War II, played a very influential behind-thescenes role in post-Mandate Baghdad as a British adviser embedded with the Iraqi government. 
2 As a historical source East and West of Zagros is valuable on (at least) three counts. Firstly, Edmond's ability to observe his surroundings and the people inhabiting them with quasi anthropological acuity enhances our understanding of Iran's social and cultural history at the local and regional level greatly, as long as the temptation can be resisted to take his numerous personal judgments of individuals at face value. Secondly, Edmonds occupied a rather particular position within the framework of Britain's war-time and post-war intervention in Persia: as a Political officer, he operated at the nexus of warfare and diplomacy. Thus, his account allows for unique insights into how British military activities and British diplomatic measures, which were often conducted in far from perfect harmony with one another, played out on the ground in interaction with Iranian interlocutors as well as with representatives of other intervening powers, be them friends or foes. Thirdly, and lastly, Edmond's personal narrative permits studying the mentality as well as, and perhaps even first and foremost, the governmentality, of a particular type of official engaged in Britain's overseas involvement that is frightfully efficient and, if need be, ruthless in their service to British imperialism but at the same time also extremely erudite, highly linguistically capable and, above all, intellectually curious, which, in their attempt at making sense of their non-European Other, allows them to (occasionally) burst the straightjacket of prejudices and discursive constraints, into which they were fashioned by the social imaginary of their times.

3 Basing his edition on the author's manuscript held at the archives of the Middle East Centre at St Antony's College Oxford, Yann Richard presents these memoirs very perceptively by drawing on related documents also located at St Antony's, such as for instance Edmond's diaries covering the period, but also, in his annotations, by bringing to bear his intimate familiarity with the history of this era and, especially, its bewildering cast of Iranian and foreign actors of whom he helpfully provided a detailed, 30-page appendix containing biographical indices. He also took care to illustrate the text pertinently with a number of carefully selected images as well as with a number of maps while furthermore furnishing a supplementary bibliography and an index.

In sum, there can be little doubt as to the fact that scholars will welcome being able to use this edition of a hitherto inaccessible major primary source thanks to Yann Richard who succeeded in setting C.J. Edmonds's richly detailed yet highly readable autobiographical narrative appositely and insightfully into its historical context.

\section{AUTEURS}

\section{OLIVER BAST}

Université Sorbonne Nouvelle, Mondes iranien et indien 